\section{Efficiency of Prebiotics and Probiotics on the Performance, Yield, Meat Quality and Presence of Salmonella spp in Carcasses of Free-Range Broiler Chickens}

- Author(s)
Takahashi SE'
Mendes $\mathrm{AA}^{2}$
Saldanha ESPB
Pizzolante $\mathrm{CC}^{3}$
Pelícia $\mathrm{K}^{1}$
Quinteiro RR ${ }^{1}$
Komiyama $\mathrm{CM}^{1}$
Garcia RG'
Almeida Paz ICL'1
1 Graduate student in Animal Science,
Faculdade de Medicina Veterinária e
Zootecnia, UNESP, Campus de Botucatu, SP.
2 Professor, Departamento de Produção e
Exploração Animal, Faculdade de Medicina
Veterinária e Zootecnia UNESP, Campus de
Botucatu, SP.
3 Scientist, Unidade de Pesquisa de Brotas from
Agência Paulista de Tecnologia dos
Agronegócios, SP.

\section{Mail Address}

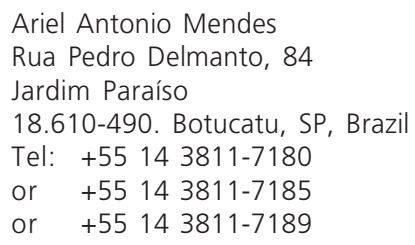

Carcass yield, free-range broilers, performance, prebiotics and probiotics, Salmonella spp.

Research support by EMBRAPA (Empresa Brasileira de Pesquisa Agropecuária - Concórdia $\mathrm{SC})$

\section{ABSTRACT}

Two trials were carried out in the present study. Trial I evaluated the performance, carcass yield and breast meat quality, whereas Trial II evaluated the efficacy of utilizing prebiotics + probiotics on the control of Salmonella spp incidence in the carcasses of free-range broilers. In Trial I, 688 one-day-old male chicks of the Naked Neck Label Rouge strain were used, distributed in a randomized block design arranged according to a $2 \times 2$ factorial: control diet or diet supplemented with probiotics and prebiotics; and two rearing systems (confined or with access to paddocks $-3 \mathrm{~m}^{2} /$ bird), using four replicates with 35 birds each. The birds were reared until 84 days of age following the recommendations of management and nutrition for free-range strains, and had access to paddocks after 35 days of age. Water and food were given inside the experimental poultry house. Birds fed probiotics and prebiotics in the diet and the confined birds showed better performance, carcass yield and meat quality compared to the birds of the other treatments. In Trial II, 128 one-day-old male chicks of the free-range Naked Neck Label Rouge strain were used. The birds were distributed into four treatments: NCC (non-challenged control), NCS (non-challenged supplemented), CC (challenged control) and CS (challenged supplemented). There were no significant effects of adding probiotics and prebiotics in the diet in regard to Salmonella enteritidis recovery from the carcasses.

\section{INTRODUCTION}

There is an increasing tendency worldwide to adopt more natural or organic management techniques in broiler rearing and in Brazil as well. Consumers have been looking for a "more natural" food, although this is more of a perceptive issue than a technical one.

Free-range broiler rearing is one of the animal production systems that have been controlled by Decree $N^{\circ} 007 / 99$ from the Division of Industrial Operations of the Department of Inspection of Animal Products from the Ministry of Agriculture (Brasil, 1999). The regulation prohibits the use of chemical growth promoters and coccidiostats, and thus the control of pathogenic microorganisms, such as Clostridium, salmonellas and others, becomes a more difficult task.

The use of probiotics as food additives has the objective of preventing the intestinal colonization of enteropathogenic microorganisms in birds, since the probiotics and the pathogenic bacteria compete for nutrients (Silva, 2000) and for adhesion sites on the intestinal epithelium (Nurmi \& Rantala, 1973). Probiotics might also produce antimicrobial substances (organic acids and bacteriocins) and enzymes (Andreatti Filho \& Sampaio, 1999), and stimulate intestinal immunity (Ouwerhand et al., 1999). In the past years, probiotics have been proposed as natural substitutes for 
Takahashi SE, Mendes AA, Saldanha ESPB, Pizzolante CC, Pelícia K, Quinteiro RR, Komiyama CM, Garcia RG, Almeida Paz ICL

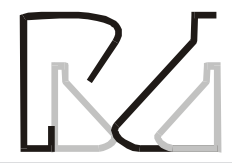

Efficiency of Prebiotics and Probiotics on the Performance, Yield, Meat Quality and Presence of Salmonella spp in Carcasses of Free-Range Broiler Chickens chemical promoters included in animal diets. The use of probiotics has started after a study reported by Nurmi \& Rantala (1973), and the original objective was to control Salmonella infections in birds.

The major action of prebiotics is to stimulate the growth and/or activate the metabolism of some groups of beneficial bacteria in the intestinal tract, acting in association with probiotics. Therefore, the association between prebiotics and probiotics is technically indicated and some commercial products are already available.

Diseases might be transmitted to humans through food, particularly products of animal origin. Salmonella spp is the major etiologic agent (Uyttendaele et al., 1998 and Doyle, 1994) and eggs, bird carcasses and poultry products play major roles in disease transmission to humans (Andreatti Filho et al., 1997 and 2000).

In order to control food infection caused by Salmonella spp in humans, it is crucial that an effective inspection of the food production lines and/or later steps of industrial processing, distribution, commercialization and consumption is performed. Bird infection may occur orally or vertically, i.e., the contaminated egg produces a naturally infected chick (Desmidt et al., 1997). Nevertheless, during the slaughter processes, enteropathogenic organisms might contaminate carcasses during evisceration, which may represent a possible transmission route of this agent to human beings (Uyttendaele et al., 1998).

Birds are more susceptible to infection by Salmonella spp in the first week of age (Desmidt et al., 1997 and Edens, 1999). Nevertheless, the infection generally becomes self-limiting with aging or the number of colonies is drastically reduced, and the disease is no longer detected (Andreatti Filho et al., 2000).

This study evaluated the effects of supplementing the diet with a commercial product composed of an association between prebiotics and probiotics (Simbiótico plus ${ }^{\circledR}$ ) on the performance, carcass yield, meat quality and the presence of Salmonella spp in the carcass of free-range broilers reared until 84 days of age.

\section{MATERIAL AND METHODS}

The first trial was carried out at the experimental facilities of Unidade de Pesquisa e Desenvolvimento de Brotas, of the Secretary of Agriculture of the State of São Paulo. The second trial was carried out at the experimental facilities of Faculdade de Medicina Veterinária e Zootecnia (FMVZ) from UNESP, Botucatu Campus. Each trial lasted 12 weeks.
Trial I: One-day-old free-range male broilers of the Naked Neck Label Rouge strain were used. There were 688 chicks distributed in a randomized block design according to a $2 \times 2$ factorial (control diet and diet supplemented with probiotics and prebiotics; two rearing systems, confined and with access to a paddock - $3 \mathrm{~m}^{2} / \mathrm{bird}$ ), with four repetitions and 35 birds per repetition.

Trial II: one-day-old male chicks from the Naked Neck Label Rouge strain were used. There were 128 chicks distributed in four treatments: NCC (nonchallenged control birds), NCS (non-challenged and supplemented), CC (challenged control birds) and CS (challenged and supplemented).

Before housing the birds, 5 chicks were randomly chosen and necropsied. Laboratory analyses were performed in order to assure the absence of Salmonella in this flock of birds (Andreatti Filho et al., 2000). On the third day, CC and CS birds were challenged with $10^{6}$ CFU of the enteritidis strain, phagotype 4, using $0.5 \mathrm{ml}$ of oral inoculum per bird (Andreatti Filho et al., 2000).

In the first trial, the birds reared in the semi-confined system had free access to grass paddocks $\left(3 \mathrm{~m}^{2} / \mathrm{bird}\right)$ after 35 days of age during the day and were kept in pens during the night.

Chicks were vaccinated in the hatchery against Marek's disease and coccidiosis and against fowl pox at 15 days of age.

Feed and water were provided ad libitum throughout the rearing period and the feeding program was divided into three phases (1 to 28, 29 to 63 and 64 to 84 days of age) as recommended by Figueiredo (2000). The percentage composition of the diets and calculated values are shown in Table 1.

Mash diets were prepared without chemical growth promoters, coccidiostats or products of animal origin. Simbiótico plus ${ }^{\circledR}$ (BioCamp Laboratórios Ltda, Campinas, SP) was added to the diets of supplemented groups. This commercial product is composed of probiotics and prebiotics, and contains $10^{6} \mathrm{CFU}$ of Enterococcus sp per gram of product and $85 \%$ of mannanoligosaccharides.

Feed intake, weight gain and feed conversion were calculated weekly and mortality was recorded daily in Trial I. All dead birds were weighed and the weight was used to correct feed intake data. At 84 days of age, three birds per parcel were randomly chosen and killed after fasting for 8 hours. Yields of carcass and cuts were calculated on body weight basis (immediately before slaughter) and on carcass weight basis, using 
Takahashi SE, Mendes AA, Saldanha ESPB, Pizzolante CC, Pelícia K, Quinteiro RR, Komiyama CM, Garcia RG, Almeida Paz ICL
Efficiency of Prebiotics and Probiotics on the Performance, Yield, Meat Quality and Presence of Salmonella spp in Carcasses of Free-Range Broiler Chickens the eviscerated carcass without neck and legs. Abdominal fat pad (including fat surrounding gizzard and cloaca) was removed and weighed separately. The following cuts were evaluated: breast, legs (drumsticks and thighs), back and wings. Determinations were performed according to Mendes (1990). Viscera were also sampled (liver, gizzard, spleen, small and large intestines) and weighed to calculate the relative weight (organ weight/body weight). The gizzard was weighed after the fat and contents had been removed. The length of the small and large intestines were measured and expressed in centimeters.

\begin{tabular}{|c|c|c|}
\hline \multicolumn{3}{|c|}{$\begin{array}{l}\text { Table } 1 \text { - Percentage composition and calculated analysis of the } \\
\text { experimental diets. }\end{array}$} \\
\hline Ingredients $\quad 1$ to 28 days & 29 to 63 days & 64 to 84 days \\
\hline 60.72 & 66.38 & 72.63 \\
\hline Soybean meal & 29.28 & 23.70 \\
\hline Dicalcium phosphate & 1.74 & 1.49 \\
\hline Limestone & 1.19 & 1.25 \\
\hline Soybean oil & 0.57 & 0.10 \\
\hline Salt & 0.35 & 0.35 \\
\hline DL-Methionine & 0.09 & 0.08 \\
\hline Vitamin Supplement ${ }^{1}$ & 0.10 & 0.10 \\
\hline Mineral supplement ${ }^{2}$ & 0.10 & 0.10 \\
\hline Symbiotics & 0.20 & 0.20 \\
\hline Total & 100.0 & 100.0 \\
\hline \multicolumn{3}{|l|}{ Calculated Values } \\
\hline $\mathrm{ME}, \mathrm{kcal} / \mathrm{kg}$ & 2,900 & 2,900 \\
\hline$C P, \%$ & 18.00 & 16.50 \\
\hline Lysine, \% & 0.88 & 0.78 \\
\hline Methionine, \% & 0.38 & 0.35 \\
\hline Calcium, \% & 1.00 & 0.95 \\
\hline Available Phosphorus, \% 0.46 & 0.43 & 0.38 \\
\hline \multicolumn{3}{|c|}{ 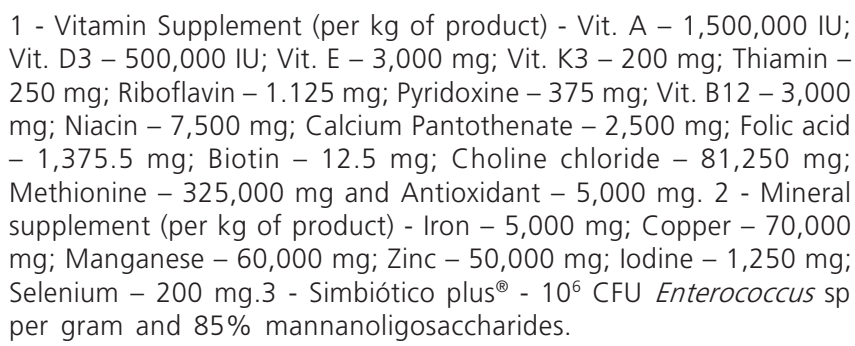 } \\
\hline
\end{tabular}

In Trial II, birds were slaughtered at 3, 6, 9 and 12 weeks of age. Three birds were randomly taken from each treatment in each sampling day. Eviscerated carcasses were identified and placed into plastic bags containing $300 \mathrm{ml}$ of buffered peptone water and then washed for 3 minutes (Cox et al., 1978). The rinse water was transferred to enrichment media (tetrathionate and selenite) and incubated at $37^{\circ} \mathrm{C}$ for 24 hours. The material was streaked onto MacConkey agar plates and brilliant green agar plates and incubated at $37^{\circ} \mathrm{C}$ for 24 hours. Suspected Salmonella colonies were biochemically analyzed to characterize the presence of Salmonella enteritidis in the samples.
The results of Trial I were submitted to analysis of variance and different means were compared by the Tukey's Test using the GLM procedure (General Linear Models) of the statistical software SAS (SAS Institute, 1996). The results from Trial II were analyzed using the non-parametric Kruskal-Wallis method.

\section{RESULTS AND DISCUSSION}

Performance data from the first trial are shown in Table 2. Mortality was significantly affected by the diet in the first phase ( 1 to 35 days); control birds showed higher mortality rates. These findings are in accordance with data reported by Pelícia (2004).

During the growth phase (36 to 63 days), there was a significant effect of diet on feed conversion, and control birds showed poor feed conversion. The rearing system also affected weight gain and feed intake, so that confined birds had better weight gain and feed intake. These findings corroborate results reported by Jensen \& Jensen (1982), but disagree from those reported by Loddi et al. (1998), Cavazzoni et al. (1993) and Khan et al. (1992).

Diet significantly affected body weight, weight gain and feed intake only in the final phase (64 to 84 days). Birds fed diets supplemented with probiotics and prebiotics showed greater body weight and weight gain, whereas feed intake was greater in control birds The results are in accordance with findings reported by Loddi et al. (1998), in which best performance was seen in birds that had not been fed antibiotics as growth promoters in the diet.

The negative effect on performance shown by some treatments supplemented with probiotics might be a consequence of the fact that birds have been reared in an environment with excellent prophylactic conditions, and therefore have not been submitted to challenges. An unbalance of the intestinal microflora might have occurred due to the supplementation in higher quantities than the levels normally present in the digestive tract. Therefore, the microorganisms responsible for promoting growth might have become "infecting" agents and probably suppressed the metabolism and absorption of nutrients. Consequently, bird performance has also been suppressed (Tournut, 1998).

Table 3 presents the yields of carcass and parts. Diet significantly affected $(p<0.05)$ body weight, carcass yield and yields of breast and legs.

The rearing system significantly affected $(p<0.05)$ weight gain, carcass yield, back yield, and percentage 
Takahashi SE, Mendes AA, Saldanha ESPB, Pizzolante CC, Pelícia K, Quinteiro RR, Komiyama CM, Garcia RG, Almeida Paz ICL
Efficiency of Prebiotics and Probiotics on the Performance, Yield, Meat Quality and Presence of Salmonella spp in Carcasses of Free-Range Broiler Chickens

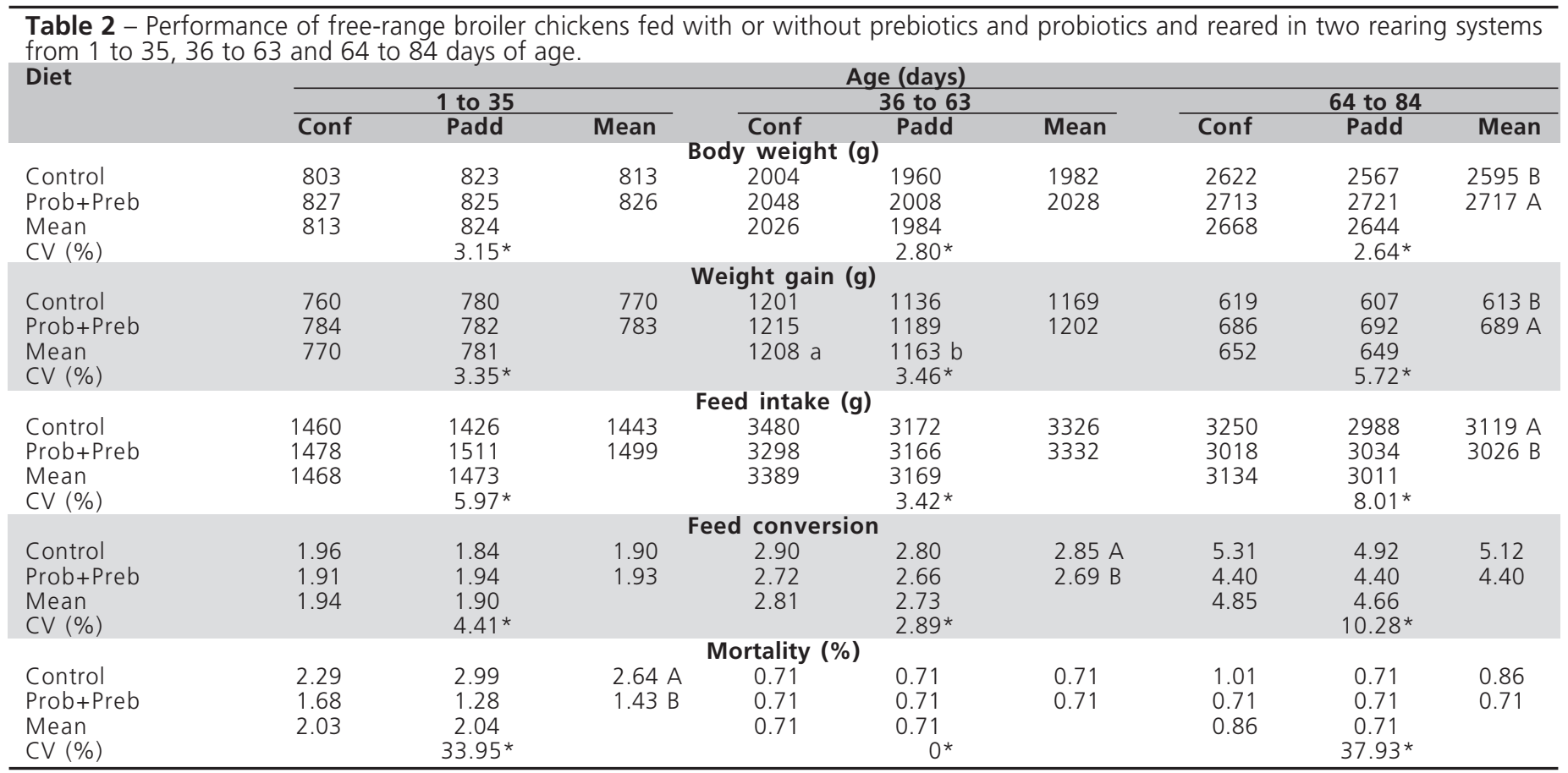

a, b, A, B - Means followed by different small letters in the rows and capital letters in the columns are different according to the Tukey's test $(p<0.05)$. Conf=confined system, Padd=Paddock (semi-confined system). Pro+Pre=diet with probiotics and prebiotics.

Table 3 - Body weight, yields of carcass and parts of free-range chickens fed with or without probiotics and prebiotics in two different rearing systems (84 days of age).

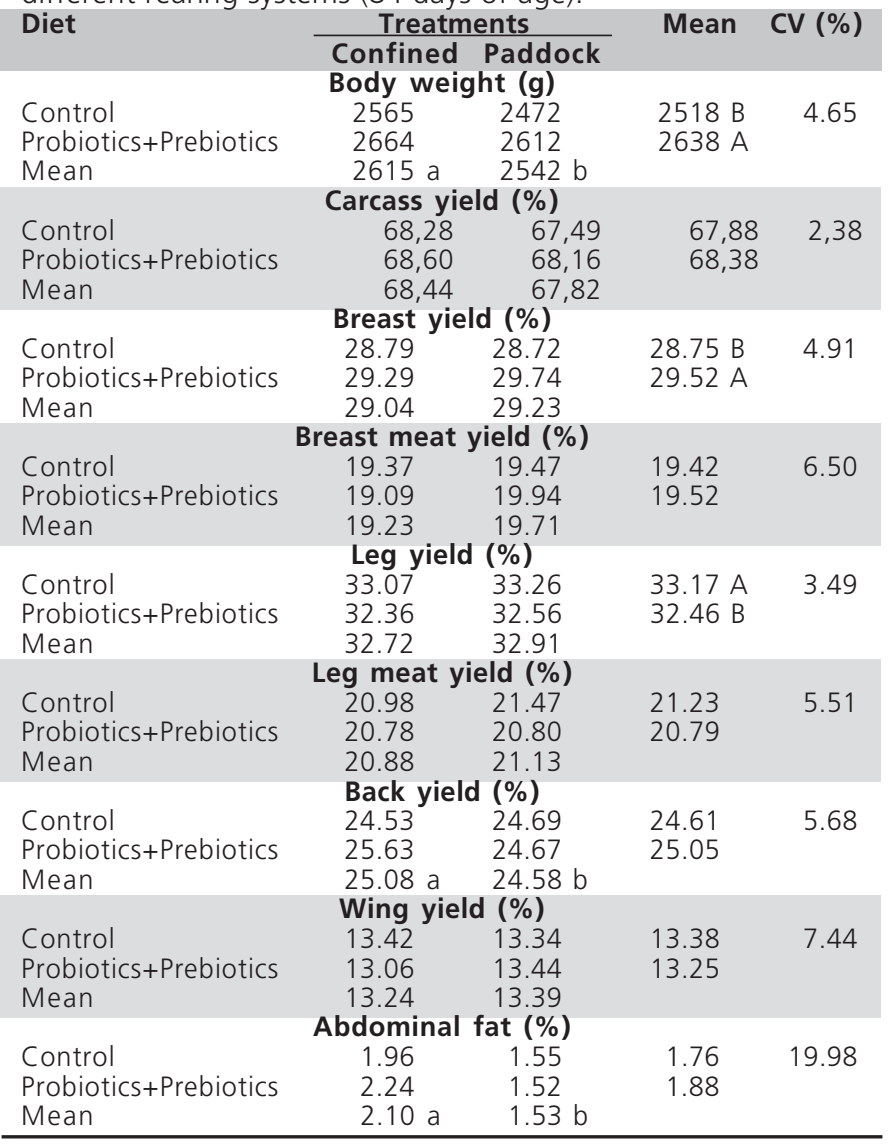

$a, b, A, B$ - Means followed by different small letters in the rows and capital letters in the columns are different according to the Tukey's test $(p<0.05)$. of abdominal fat, so that better results were seen for birds reared in the confined system. The results of body weight are in accordance with the findings of Pelícia et al. (2003). Conversely, it has been observed in a previous study that broiler chickens fed antibiotics and probiotics showed no significant difference in carcass yields (Henrique et al., 1998).

The results of meat quality are shown in Table 4 . There was a significant effect of diet on breast fillet height and length. Higher height and length of breast fillet were seen in birds fed the diet containing probiotics and prebiotics.

The rearing system affected the length of the breast filet. Confined birds had longer filets in comparison to birds with access to paddocks. Conversely, a previous study (Pelícia, 2004) reported meat quality characteristics similar between free-range broiler chickens fed diets with different additives (probiotics, prebiotics and antibiotics).

The measurements of the gastrointestinal tract are shown in Table 5. Control birds showed higher $(p<0.05)$ percentages of liver and ileum. Henrique et al. (1998) have also found significant differences for liver percentages. Spleen and gizzard percentages were not affected by the addition of probiotics and prebiotics, corroborating previous results reported by Loddi et al. (2000).

The present findings are in accordance with data observed by Fethiere (1987), who reported higher 
Takahashi SE, Mendes AA, Saldanha ESPB, Pizzolante CC, Pelícia K, Quinteiro RR, Komiyama CM, Garcia RG, Almeida Paz ICL
Efficiency of Prebiotics and Probiotics on the Performance, Yield, Meat Quality and Presence of Salmonella spp in Carcasses of Free-Range Broiler Chickens
Table 4 - Breast and leg meat quality of free-range broiler chickens fed with or without prebiotics and probiotics in two rearing systems, at 84 days of age.

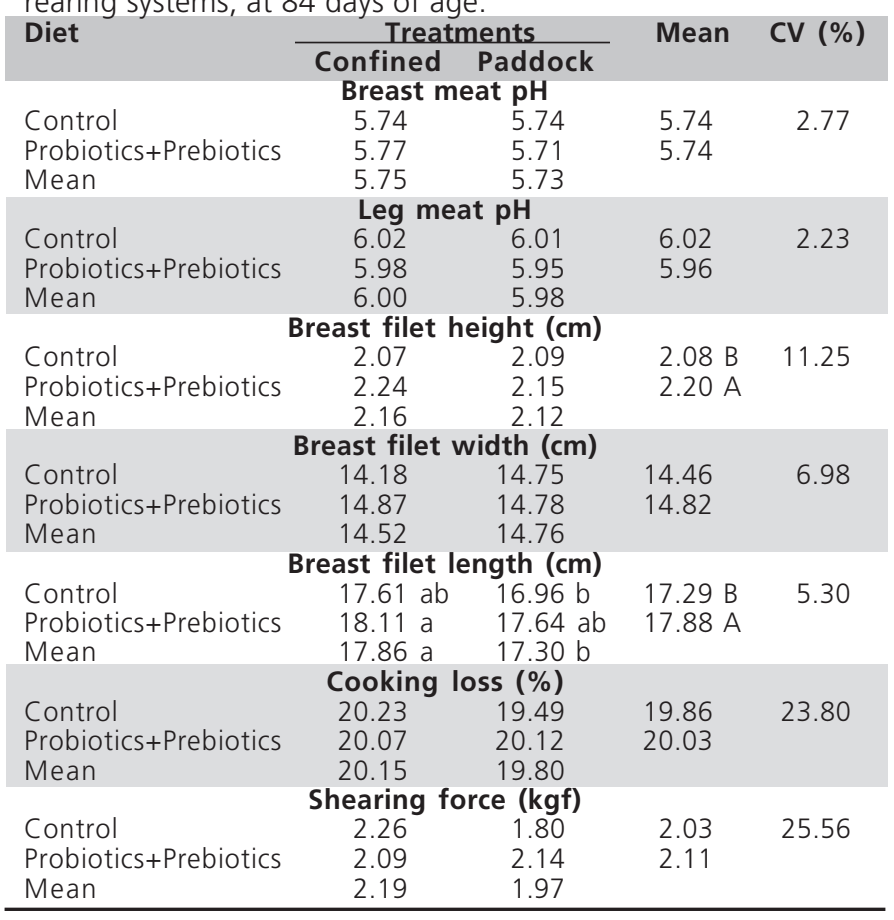

$a, b, A, B$ - Means followed by different small letters in the rows and capital letters in the columns are different according to the Tukey's test $(p<0.05)$ weights of the small intestine of birds fed biological additives in the diet. There was a significant effect of rearing system on the percentages of gizzard and jejunum, which were higher in confined birds.

Rodrigues et al. (2003) evaluated morphometric characteristics of 49-day-old broiler chickens that had been fed pre-starter diets with different physical forms. The different forms of the diet fed from 1 to 7 days of age had no effects ( $p>0.05)$ on the relative weight or the length of gizzard + proventriculus + small intestine. The lengths of the small intestines were 165, 176, 171 and 168 centimeters for mashed, crushed, pelleted and extruded pre-initial diets, respectively.

Pelícia et al. (2003) reported significant differences only in the length and the percentage of large intestine between the birds of Naked Neck strain that were fed diets with prebiotics, probiotics and coccidiostats, and the birds of group 4, that were fed antibiotics and coccidiostats.

In Trial II, laboratory analyses of day-old chicks indicated absence of Salmonella spp in the flock. There were no significant differences between treatments for the presence of Salmonella, including data collected in the sixth week (Table 6).

\begin{tabular}{|c|c|c|c|c|c|}
\hline \multirow[t]{2}{*}{ Diet } & & \multicolumn{2}{|c|}{ Treatments } & \multirow[t]{2}{*}{ Mean } & \multirow[t]{2}{*}{ CV (\%) } \\
\hline & & Confined & Paddock & & \\
\hline \multirow[t]{3}{*}{ Gizzard (\%) } & Control & 1.82 & 2.08 & 1.95 & \multirow[t]{3}{*}{17.60} \\
\hline & Probiotics+Prebiotics & 1.71 & 1.88 & 1.79 & \\
\hline & Mean & $1.98 \mathrm{a}$ & $1.76 \mathrm{~b}$ & & \\
\hline \multirow[t]{3}{*}{ Liver (\%) } & Control & 1.56 & 1.58 & $1.57 \mathrm{~A}$ & \multirow[t]{3}{*}{12.16} \\
\hline & Probiotics+Prebiotics & 1.44 & 1.51 & $1.47 \mathrm{~B}$ & \\
\hline & Mean & 1.50 & 1.54 & & \\
\hline \multirow[t]{3}{*}{ Spleen (\%) } & Control & 0.18 & 0.17 & 0.18 & \multirow[t]{3}{*}{25.69} \\
\hline & Probiotics+Prebiotics & 0.19 & 0.16 & 0.17 & \\
\hline & Mean & 0.18 & 0.17 & & \\
\hline \multirow[t]{3}{*}{ Duodenum (\%) } & Control & 0.44 & 0.45 & 0.45 & \multirow[t]{3}{*}{14.02} \\
\hline & Probiotics+Prebiotics & 0.46 & 0.43 & 0.44 & \\
\hline & Mean & 0.45 & 0.44 & & \\
\hline \multirow[t]{3}{*}{ Duodenum $(\mathrm{cm})$} & Control & 24.50 & 24.50 & 24.50 & \multirow[t]{3}{*}{9.77} \\
\hline & Probiotics+Prebiotics & 24.92 & 24.42 & 24.67 & \\
\hline & Mean & 24.71 & 24.46 & & \\
\hline \multirow[t]{3}{*}{ Jejunum (\%) } & Control & 1.00 & 0.88 & 0.95 & \multirow[t]{3}{*}{14.92} \\
\hline & Probiotics+Prebiotics & 0.96 & 0.85 & 0.90 & \\
\hline & Mean & $0.98 \mathrm{a}$ & $0.87 \mathrm{~b}$ & & \\
\hline \multirow[t]{3}{*}{ Jejunum (cm) } & Control & 62.16 & 57.83 & 60.00 & \multirow[t]{3}{*}{11.70} \\
\hline & Probiotics+Prebiotics & 56.92 & 56.92 & 56.92 & \\
\hline & Mean & 59.54 & 57.38 & & \\
\hline \multirow[t]{3}{*}{ Ileum (\%) } & Control & 0.83 & 0.86 & $0.85 \mathrm{~A}$ & \multirow[t]{3}{*}{16.85} \\
\hline & Probiotics+Prebiotics & 0.81 & 0.72 & $0.77 \mathrm{~B}$ & \\
\hline & Mean & 0.82 & 0.79 & & \\
\hline \multirow[t]{3}{*}{ Ileum (cm) } & Control & 62.92 & 57.08 & 60.00 & \multirow[t]{3}{*}{10.90} \\
\hline & Probiotics+Prebiotics & 58.50 & 57.42 & 57.96 & \\
\hline & Mean & 60.71 & 57.25 & & \\
\hline \multirow[t]{3}{*}{ Cecum (\%) } & Control & 0.75 & 0.77 & 0.76 & \multirow[t]{3}{*}{18.56} \\
\hline & Probiotics+Prebiotics & 0.74 & 0.77 & 0.75 & \\
\hline & Mean & 0.77 & 0.74 & & \\
\hline \multirow[t]{3}{*}{ Cecum (cm) } & Control & 43.75 & 44.58 & 44.16 & \multirow[t]{3}{*}{8.99} \\
\hline & Probiotics+Prebiotics & 43.75 & 41.92 & 42.83 & \\
\hline & Mean & 43.75 & 43.25 & & \\
\hline
\end{tabular}

a, b, A, B - Means followed by different small letters in the rows and capital letters in the columns are different according to the Tukey's test $(p<0.05)$. 
Takahashi SE, Mendes AA, Saldanha ESPB, Pizzolante CC, Pelícia K, Quinteiro RR, Komiyama CM, Garcia RG, Almeida Paz ICL
Efficiency of Prebiotics and Probiotics on the Performance, Yield, Meat Quality and Presence of Salmonella spp in Carcasses of Free-Range Broiler Chickens

\begin{tabular}{|c|c|c|c|c|}
\hline \multicolumn{5}{|c|}{$\begin{array}{l}\text { Table } 6 \text { - Isolation of Salmonella spp in carcasses of free-rang } \\
\text { broiler chickens at different ages. }\end{array}$} \\
\hline Age & & Absence & Presence & Total \\
\hline \multirow{4}{*}{3 wk } & NCC & 3 & 0 & 3 \\
\hline & NCS & 3 & 0 & 3 \\
\hline & CC & 3 & 0 & 3 \\
\hline & CS & 3 & 0 & 3 \\
\hline \multirow{4}{*}{6 wk } & NCC & 3 & 0 & 3 \\
\hline & NCS & 3 & 0 & 3 \\
\hline & $\mathrm{CC}$ & 1 & 2 & 3 \\
\hline & CS & 3 & 0 & 3 \\
\hline \multirow{4}{*}{9 wk } & NCC & 3 & 0 & 3 \\
\hline & NCS & 3 & 0 & 3 \\
\hline & CC & 3 & 0 & 3 \\
\hline & CS & 3 & 0 & 3 \\
\hline \multirow{4}{*}{$12 \mathrm{wk}$} & NCC & 3 & 0 & 3 \\
\hline & NCS & 3 & 0 & 3 \\
\hline & CC & 3 & 0 & 3 \\
\hline & CS & 3 & 0 & 3 \\
\hline
\end{tabular}

p > 0.05 according to the test of Kruskal-Wallis. NCC - non-challenged control, NCS - non-challenged supplemented, CC - challenged control, CS - challenged supplemented.

The results of Salmonella isolation are shown in Table 6. Salmonella was not recovered from the carcasses of challenged birds at 9 and 12 weeks of age. This might be due to the fact that Salmonella infection becomes self-limiting with age, or the number of colonies might be drastically reduced and thus the disease is no longer noticed (Andreatti Filho et al., 2000). It is also possible that no Salmonella has been isolated from the carcasses because it is present inside the intestines and, since manual evisceration was performed correctly and there was no contact between the gastrointestinal contents and the carcass, carcasses were not contaminated with Salmonella during processing.

The use of a product containing probiotics and prebiotics in contaminated flocks challenged with Salmonella enteritidis has significantly reduced carcass contamination with Salmonella spp (Caramori Jr., 2001).

\section{CONCLUSION}

The rearing of free-range broiler chickens according to the guidelines proposed by the Brazilian Legislation is viable, considering that the use of probiotics, prebiotics and vaccination against coccidiosis resulted in better results of performance, carcass yield and meat quality when compared to the control birds. Furthermore, carcasses were not contaminated with Salmonella enteritidis.

\section{REFERENCES}

Andreatti Filho RL, Silva EN, Cury PR. Ácidos orgânicos e microbiota cecal anaeróbia no controle da infecção experimental de frangos por Salmonella Typhimurium e Salmonella Enteritidis. Arquivo Brasileiro de Medicina Veterinária e Zootecnia 1997; 49:661-72.

Andreatti Filho RL, Sampaio HM. Probióticos e prebióticos: Realidade na avicultura industrial moderna. Revista de Educação Continuada do CRMV-SP 1999; 2(3):59-71.

Andreatti Filho RL, Silva EN, Ribeiro AR, Kondo N, Curi PR. Use of anaerobic cecal microflora, lactose and acetic for the protection of broiler chicken against experimental infection with Salmonella Typhimurium and Salmonella Enteritidis. Brazilian Journal of Microbiology 2000; 32:107-12.

Brasil. Ministério da Agricultura, Pecuária e Abastecimento. Ofício Circular DOI/DIPOA No007/99, 19 de maio de 1999. Brasília, DF.

Caramori Jr JG. Efeito de probióticos e prebióticos na ração de frangos de corte sobre o desempenho, rendimento de carcaça, características químicas e presença de Salmonella spp na carne [tese]. Botucatu (SP): Universidade Estadual Paulista; 2001.

Cavazzoni V, Adami A, Castrovilli C, Succi G. A preliminary experimentation on broilers with a strain of Bacillus coagulans as probiotic. Microbiologie Aliments Nutrition 1993; 11:457-62.

Cox NA, Mercuri AJ, Tanner DA, Carson MO, Thomson JE, Bailey JS. Effectiveness of sampling methods for Salmonella detection on processed broilers. Journal Food Protein 1978; 41:341-3.

Desmidt M, Ducatelle R, Haesebrouck F. Pathogenesis of Salmonella Enteritidis phage type four after experimental infection of young chickens. Veterinary Microbiology 1997; 56:99-109.

Doyle MP. The emergence of new agents of foodborne disease in the 1980s. Food Research 1994; 27: 219-26.

Edens FW. Mecanismo de competição exclusiva. In: Conferência APINCO 1999 de Ciências e Tecnologia Avícolas; 1999; Santos. p.38-9.

Fethiere R. Intestinal tract weight of chicks fed an antibiotic and probiotic. Nutrition Reports International 1987; 36(6):1305-9.

Figueiredo EAP, Ávila VS, Brum PAR. et al. Frango de corte colonial EMBRAPA 041-folder da linhagem. Concórdia: EMBRAPA Suínos e Aves, 2000. 8p.

Henrique APF, Faria DE, Franzolin R, Ito DT. Uso de probióticos e antibióticos como promotores de crescimento para frangos de corte. In: $35^{\circ}$ Reunião Anual da Sociedade Brasileira de Zootecnia; 1998; Botucatu. p.297-9.

Jensen JF, Jensen MM. The effect of using growth promoting Bacillus strains in poultry feed. In: $18^{\circ}$ World's Poultry Congress; 1982; Amsterdam, 3:398-402. 
Takahashi SE, Mendes AA, Saldanha ESPB, Pizzolante CC, Pelícia K, Quinteiro RR, Komiyama CM, Garcia RG, Almeida Paz ICL
Efficiency of Prebiotics and Probiotics on the Performance, Yield, Meat Quality and Presence of Salmonella spp in Carcasses of Free-Range Broiler Chickens

Khan ML, Ullah I, Javed MT. Comparative study of probiotics, t.m. 50 biovin-40 and albac on the performance of broiler chicks. Pakistan Veterinary Journal 1992; 12:145-57.

Loddi MM, Gonzales E, Takita TS, Leandro NM, Mendes AA. Efeito da adição de probiótico e antibiótico como promotores de crescimento sobre o desempenho de frangos de corte. In: $35^{\circ}$ Reunião Anual da Sociedade Brasileira de Zootecnia; 1998; Botucatu. p.189-90.

Loddi MM, Gonzales E, Takita TS. Uso de probiótico e antibiótico sobre o desempenho, rendimento e a qualidade de carcaça de frangos de corte. Revista Brasileira de Zootecnia 2000; 29 (4):1124 $-31$.

Mendes AA. Efeito de fatores genéticos, nutricionais e de ambiente sobre o rendimento de carcaça de frangos de corte [tese]. Botucatu (SP): Universidade Estadual Paulista; 1990.

Nurmi E, Rantala M. New aspects of Salmonella infection in broiler production. Nature 1973; 241: 210-211.

Ouwerhand AC, Kirjavainen PV, Short C et al. Probiotics: mechanisms and established effects. International Dairy Journal 1999; 9:43-52.

Pelícia K, Mendes AA, Saldanha ESP, Pizzolante CC, Takahashi SE, Moreira J, Garcia RG, Oliveira RP, Quinteiro RR, Almeida ICL. Efeito de antibióticos, prebióticos e probióticos sobre o desempenho, rendimento de carcaça e desenvolvimento do intestino de frangos de corte tipo colonial. In: 40 Reunião Anual da Sociedade Brasileira de Zootecnia; 2003; Santa Maria. CD-ROM.

Pelícia K. Utilização de probiótico e prebiótico para frangos de corte tipo colonial [dissertação]. Botucatu (SP): Universidade Estadual Paulista; 2004.

Rodrigues EA, Junqueira OM, Laurentz AC et al. Características morfométricas de frangos de corte alimentados com rações préiniciais com diferentes formas físicas. In: $40^{\circ}$ Reunião Anual da Sociedade Brasileira de Zootecnia; 2003; Santa Maria. CD-ROM.

Statistical Analysis System. User's guide: statistics. Cary: SAS Institute; 1996.

Silva EN. Probióticos e prebióticos na alimentação de aves. In: Conferência APINCO de Ciência e Tecnologia Avícolas; 2000; São Paulo. Trabalhos de pesquisas... Campinas: FACTA; 2000. p.241251.

Tournt JR. Probioticts. In: $35^{\circ}$ Reunião Anual da Sociedade Brasileira de Zootecnia; 1998; Botucatu. p.179-199.

Uyttendaele MR, Debevere JM, Lips RM, Neyts KD. Prevalence of Salmonella in poultry and their products in Belgium. International Journal Food Microbiology 1998; 40:1-8. 